\title{
Pemulihan Ekonomi Melalui Pembangunan Kebun Bibit Desa Menggunakan Metode Participatory Action Research (PAR)
}

\author{
Afni.Z*1, Fara Merian Sari ${ }^{2}$ Prihati $^{3}$ \\ 1,2,3Fakultas Ilmu Administrasi, Universitas Lancang Kuning \\ *e-mail: afni@unilak.ac.id ${ }_{2}$ Fara.meriansari@yahoo.com ${ }_{2}^{2}$ Prihati.prihati@yahoo.com ${ }^{3}$
}

\begin{abstract}
During the Covid-19 pandemic, policies are needed in order to help economic recovery for society. This service opens public access to the policy of developing Village Seed Gardens (KBD), as an alternative to economic and environmental improvements. By using the Participatory Action Research (PAR) method with the main pillars of research, action, and participation. Partners involved in this program are seven villages in Lubuk Dalam District, Siak Regency, Riau. The results achieved were the form of community accessibility to government policies, community involvement in transformative activities to improve the economy and environment, which were obtained through assisting the development of KBD in seven villages that could independently produce thousands of seedlings for the surrounding community. Apart from economic recovery as a short-term benefit, also has long-term benefits for environmental restoration by changing degraded land to be more productive.
\end{abstract}

Keywords: Economic Recovery, Village Nursery, Environmental Policy

\begin{abstract}
Abstrak
Di masa pandemi Covid-19 Corona, masyarakat memerlukan kebijakan yang bisa membantu pemulihan ekonomi. Pengabdian ini membuka akses masyarakat pada kebijakan pembangunan Kebun Bibit Desa (KBD), sebagai alternatif perbaikan ekonomi dan lingkungan. Menggunakan metode Participatory Action Research (PAR) dengan pilar utama riset, aksi, dan partisipasi. Mitra yang terlibat dalam program ini tujuh Kampung di Kecamatan Lubuk Dalam, Kabupaten Siak, Riau. Hasil yang dicapai berupa aksesibilitas masyarakat pada kebijakan pemerintah, pelibatan masyarakat dalam kegiatan transformatif perbaikan ekonomi dan lingkungan, yang didapat melalui pendampingan pembangunan KBD yang dapat memproduksi ribuan bibit secara mandiri, yang jenisnya disesuaikan dengan permintaan dan kebutuhan masyarakat penerima. Selain pemulihan ekonomi sebagai manfaat jangka pendek, KBD juga bermanfaat jangka panjang untuk pemulihan lingkungan dengan mengubah lahan kritis menjadi lebih produktif.
\end{abstract}

Kata kunci: Pemulihan Ekonomi, Kebun Bibit Desa, Kebijakan Lingkungan

\section{PENDAHULUAN}

Pandemi Covid-19 yang melanda Indonesia sejak awal tahun 2020 telah memberi pengaruh pada banyak aspek kehidupan masyarakat, terutama pada aspek ekonomi dan sosial. Kondisi pandemi berpotensi menambah jumlah pengangguran, bahkan Badan Perencanaan Pembangunan Nasional (Bappenas) memproyeksikan peningkatan jumlah pengangguran hingga 4,22 juta orang (Chairani,2020).

Kepala BPS Suhariyanto (Kompas.com, 2020) menjelaskan peningkatan jumlah penduduk miskin meningkat disebabkan kebijakan pembatasan sosial berskala besar (PSBB) untuk mencegah penyebaran pandemi. Menyikapi dampak pandemi, Presiden Joko Widodo mengeluarkan Instruksi Presiden Nomor 4 Tahun 2020 tentang refocusing kegiatan, realokasi anggaran, serta pengadaan barang dan jasa dalam rangka Percepatan penanganan Corona Virus Disease 2019 (Covid-19) pada tanggal 20 Maret 2020. (Juliani, 2020).

Seluruh Kementerian/Lembaga dan Pemerintah Daerah diminta melakukan refocusing anggaran dengan prioritas membantu perekonomian masyarakat. Kementerian Lingkungan Hidup dan Kehutanan (KLHK) meresponnya dengan meningkatkan kinerja pelaksanaan program rehabilitasi Daerah Aliran Sungai (DAS) berbasis pelibatan kelompok masyarakat di tingkat tapak.

Pelibatan masyarakat dalam pemulihan ekonomi dan perbaikan lingkungan menjadi sangat penting, sebagaimana pandangan Chambers dan Conway dalam Ali Yansyah (2020), yang 
mengemukakan bahwa setiap rumah tangga harus melakukan strategi menghadapi dan beradaptasi agar dapat mempertahankan keberlanjutan dan resiliensi penghidupannya. Terlebih lagi peningkatan pertumbuhan penduduk dunia telah memberikan tekanan pada sumber daya alam termasuk udara, air, tanah, dan keanekaragaman hayati.(Afni, 2019)

John Rawls (2006) mengemukakan sistem ekonomi tidak hanya sebuah perangkat institusional untuk memuaskan keinginan dan kebutuhan yang ada saat ini, tapi juga cara untuk membentuk dan memenuhi keinginan-keinginan di masa depan. Pelibatan masyarakat pada kebijakan pemerintah di bidang lingkungan memiliki arti penting, karena penyebab kurang berhasilnya pencegahan dan pemulihan degradasi lahan di Indonesia, salah satunya karena komitmen yang lemah dari para pengambil dan pelaksana kebijakan, dan lemahnya komitmen masyarakat terhadap pencegahan dan pemulihan degradasi lahan.(Wahyunto, 2014).

Karena itu pelibatan masyarakat dalam kebijakan-kebijakan pemulihan lingkungan merupakan bagian dari upaya menggerakkan ekonomi masyarakat, terutama akibat dampak pandemi Covid-19. Bank Indonesia memprediksi dalam era pandemi, angka kemiskinan naik $11,25 \%$ atau 30,3 juta orang pada tahun ini, akibat pelemahan sektor transportasi, pengangkutan, perdagangan, pajak hotel dan restoran (PHR), konstruksi, pengolahan, dan pertanian.(KLHK, 2020). Sementara rehabilitasi DAS telah menjadi bagian dari masalah lingkungan yang terakumulasi dan perlu dicarikan solusi konkrit (JPNN, 2020).

Indonesia memiliki sebanyak 17.076 DAS seluas 189.278.753 Ha dan diantaranya sekitar 14,3 juta ha merupakan lahan kritis yang harus ditanami kembali. Beberapa areal atau lahan terbuka tercatat seluas 592.856 hektar pada 349 kabupaten/kota. Kawasan kritis bila tidak dilakukan pemulihan atau rehabilitasi akan menyebabkan erosi, banjir, longsor dan kekeringan. Rehabilitasi lahan yang bersifat sektoral tidak efektif, sehingga perlu melibatkan multi pihak beserta seluruh komponen yang ada, yakni pemerintah, LSM dan masyarakat dalam pengelolaan lahan kritis.(Njurumana, Susila. 2006).

Namun persoalan yang terjadi di lapangan, tidak semua masyarakat dapat mengakses dengan baik kebijakan yang dikeluarkan pemerintah. Ahmad Arif Widianto (2013) mengemukakan bahwa rendahnya aksesibilitas masyarakat terhadap kebijakan karena mereka tidak dilibatkan dalam perumusan, pelaksanaan, ataupun evaluasi kebijakan pemerintah. Hal ini membuat masyarakat tidak berdaya untuk memperbaiki kualitas ekonomi ataupun lingkungan mereka. Padahal upaya dan kebijakan inovatif perlu diambil untuk melindungi kepentingan publik dan memperkuat kehadiran negara kepada seluruh rakyat, mengantisipasi bencana ekologi, dan mengelola lingkungan sehingga setiap sektor dapat bergerak maju.(Afni, 2017)

Kecamatan Lubuk Dalam di Kabupaten Siak, memiliki tujuh Kampung, yakni Lubuk Dalam, Rawang Kao, Sri Gading, Sialang Baru, Sialang Palas, Empang Baru, dan Rawang Kao Barat. Kecamatan ini masuk dalam DAS prioritas nasional. Khairullah (2015) mengungkapkan nilai ratarata indeks penutupan lahan di DAS Siak bagian hulu didapat sebesar $12,50 \%$, sehingga termasuk dalam klasifikasi jelek dengan nilai < 30 skor 5. Untuk memperbaiki kondisi tersebut, akses kebijakan yang perlu dijangkau masyarakat adalah pembangunan Kebun Bibit Desa (KBD) yang belum pernah terbentuk sebelumnya di Kecamatan ini.

KBD adalah kebun bibit yang dibangun oleh Unit Pelaksana Teknis Direktorat Jenderal Pengendalian Daerah Aliran Sungai dan Hutan Lindung Kementerian Lingkungan Hidup dan Kehutanan (Ditjen PDASHL KLHK). Adapun bibit yang ditanam dan dibagikan ke masyarakat, merupakan jenis bibit yang diusulkan oleh kelompok masyarakat penerima program KBD. Sehingga bibit yang diproduksi dapat memberi manfaat ekonomi bagi masyarakat penerima, sekaligus manfaat pemulihan lingkungan bagi kampung pelaksana.

Pembangunan KBD dan penanaman bibit pohon produktif diharapkan dapat meningkatkan ekonomi masyarakat sekaligus penyerapan tenaga kerja (Projob) dan mengurangi tingkat kemiskinanan (Propoor) di masa pandemi. Terlebih lagi sebagaimana dikatakan Rini Nizar, dkk (2019), pertumbuhan penduduk dan bangunan mengakibatkan berkurangnya daerah 
resapan air, sehingga diperlukan kegiatan penghijauan. Dengan terbentuknya KBD melalui kegiatan pengabdian masyarakat, diharapkan dapat terpenuhinya kebutuhan rakyat dengan tetap mengedepankan perlindungan dan perbaikan lingkungan sebagai amanat UUD 1945.

\section{METODE}

Pengabdian masyarakat ini menggunakan metode Participatory Action Research (PAR), dengan terlibat secara langsung dalam penggalian informasi yang beragam, kemudian melakukan aksi sebagai solusi dari masalah yang sudah teridentifikasi, dengan ikut dalam membangun rancangan dan implementasi aksi yang didasarkan dari hasil penelitian. Adapun dasar dilakukannya PAR adalah kebutuhan untuk mendapatkan perubahan yang diinginkan. (Agus Afandi, dkk. 2013)

Melalui metode PAR, pengabdian masyarakat tidak hanya selesai dengan melakukan sosialisasi, namun dilakukan dengan penelitian dan pendampingan, serta menghubungkan semuanya dalam proses perubahan sosial di masyarakat secara bersama-sama. Hal ini menjadikan rehabilitasi DAS yang dilakukan bukan hanya sekedar proyek, melainkan pelibatan masyarakat untuk ikut serta dalam kegiatan pembangunan.(Wiratno,2020)

PAR sebagaimana disebut Dayamaya (2019) memiliki tiga pilar utama yakni dimensi riset, dimensi aksi, dan dimensi partisipasi. Tujuannya untuk mendorong aksi transformatif atau perubahan, yang dalam hal ini perubahan kondisi ekonomi dan lingkungan yang lebih baik di Kecamatan Lubuk Dalam. Untuk melakukan evaluasi kebijakan program KBD secara keseluruhan, dilakukan dengan menggunakan indikator kinerja. Menurut berbagai sumber (Bappenas,2009) indikator kinerja digunakan untuk mengukur dan memantau kinerja organisasi dan implementasi kebijakan telah sesuai dengan sasaran/tujuan yang diinginkan. Indikator kinerja yang digunakan memperhatikan 5 aspek utama yaitu indikator masukan (input), keluaran (output), hasil (outcomes), manfaat (benefit), dan dampak (impact).

\section{HASIL DAN PEMBAHASAN}

Pelaksanaan Participatory Action Research (PAR) membentuk Kebun Bibit Desa sebagai salah satu alternatif pemulihan ekonomi di masa pandemi, dilakukan dengan beberapa tahap kegiatan. Adapun hasil dan pembahasan tahapan PAR yang sudah digunakan adalah sebagai berikut:

a. Sosialisasi, FGD, dan pembagian bibit pohon gratis.

Dilaksanakan sosialisasi kebijakan pada tanggal 11 Juni 2020 pada pukul 09.30 WIB sampai pukul 12.00 Wib di aula Kantor Camat Lubuk Dalam, dengan menerapkan protokol kesehatan Covid-19. Kegiatan diikuti 35 peserta, terdiri dari seluruh Kepala Desa atau Kampung di Kecamatan Lubuk Dalam, Ketua Majelis Ulama Indonesia (MUI) Kec.Lubuk Dalam, Kepala Kantor Urusan Agama (KUA) Kec.Lubuk Dalam, Tokoh Masyarakat, Kelompok Tani, Organisasi Kepemudaan, Organiasi Perempuan, LSM, dan masyarakat Desa Lubuk Dalam. Gambar 1, 2, 3, dan 4: Kegiatan sosialisasi ini juga dihadiri Bupati Siak Alfedri, M.Si, Kepala BPDASHL Indragiri Rokan KLHK Ir.Tri Esti Indrawati, M.Si; Camat Lubuk Dalam Andi Putra S.STP,M.Si, dan Kapolsek Lubuk Dalam.

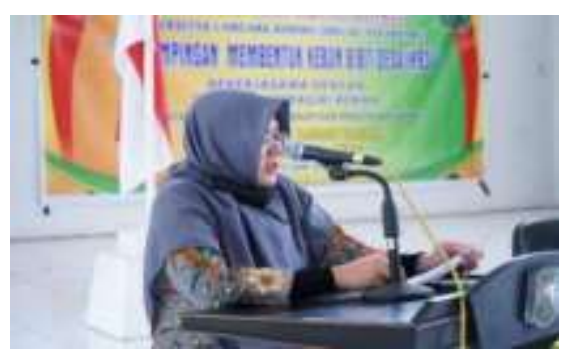

Gambar 1: Pelaksanaan sosialisasi

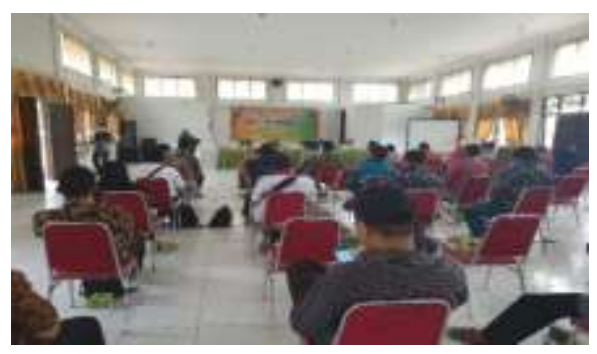

Gambar 2: Masyarakat mengikuti sosialisasi 

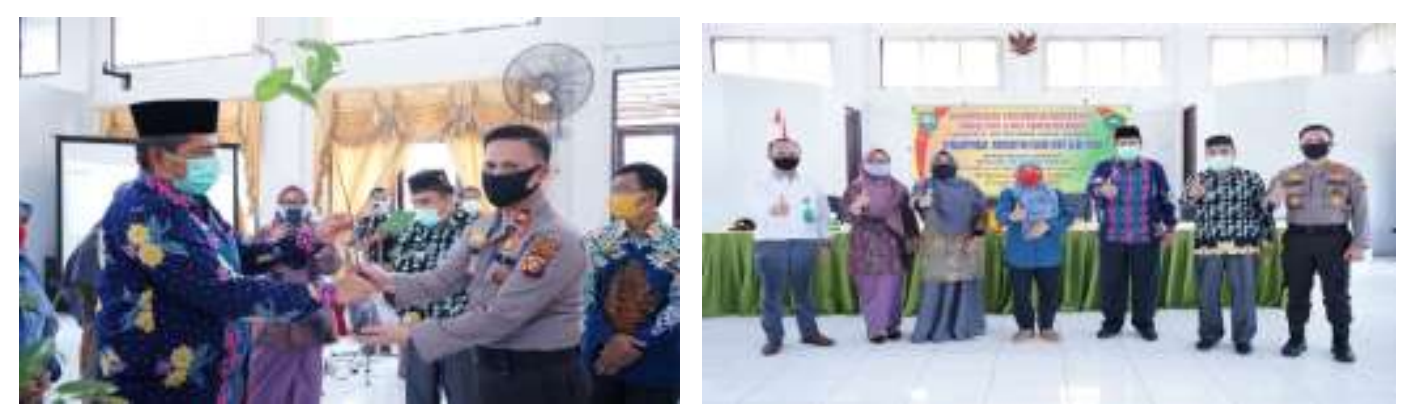

Gambar 3 dan 4: Penyerahan secara simbolis 3 Ribu bibit gratis untuk masyarakat, dan foto bersama tim pengabdian masyarakat dengan Bupati Siak dan Kepala BPDASHL Inrok

Kegiatan dilanjutkan dengan diskusi kelompok terfokus (focus group discussion/FGD). Dari kegiatan ini ditemukan gagasan dan persoalan lapangan, yang memudahkan penyusunan rencana untuk kegiatan lanjutan. Tabel 1 merupakan hasil Pre Test dan Post Test yang dibagikan kepada peserta sosialisasi.

Tabel 1: Pre Test dan Post Test Kegiatan Sosialisasi KBD

\begin{tabular}{|c|c|c|c|c|}
\hline & Pre Test & & Post Test & Pembahasan \\
\hline Pertanyaan & $\mathrm{T} / \mathrm{KT} / \mathrm{TT}$ & Pertanyaan & $\mathrm{T} / \mathrm{KT} / \mathrm{TT}$ & \\
\hline $\begin{array}{l}\text { Apakah Bapak/Ibu } \\
\text { sebelumnya } \\
\text { mengetahui } \\
\text { tentang kebijakan } \\
\text { pemerintah } \\
\text { melalui Instruksi } \\
\text { Menteri LHK } \\
\text { terkait program } \\
\text { menanam } 25 \text { bibit } \\
\text { pohon seumur } \\
\text { hidup? }\end{array}$ & $7 / 13 / 15$ & $\begin{array}{l}\text { Setelah } \\
\text { mengikuti } \\
\text { kegiatan ini, } \\
\text { apakah } \\
\text { Bapak/Ibu } \\
\text { mengetahui } \\
\text { tentang } \\
\text { kebijakan } \\
\text { pemerintah } \\
\text { melalui Instruksi } \\
\text { Menteri LHK } \\
\text { terkait program } \\
\text { menanam 25 } \\
\text { bibit pohon } \\
\text { seumur hidup? }\end{array}$ & $35 /-/-$ & $\begin{array}{l}\text { Sebanyak } 28 \text { dari } 35 \text { peserta } \\
\text { mengaku kurang tahu dan } \\
\text { tidak mengetahui sama } \\
\text { sekali kebijakan pemerintah } \\
\text { terkait program penanaman } \\
25 \text { bibit pohon seumur } \\
\text { hidup. Hanya } 7 \text { orang } \\
\text { peserta yang pernah } \\
\text { mendengar mengenai } \\
\text { kebijakan ini. Namun } \\
\text { setelah mengikuti kegiatan, } \\
\text { seluruh peserta jadi } \\
\text { mengetahui kebijakan } \\
\text { tersebut. }\end{array}$ \\
\hline $\begin{array}{l}\text { Apakah Bapak/Ibu } \\
\text { mengetahui } \\
\text { tentang } \\
\text { pentingnya } \\
\text { program } \\
\text { penghijauan } \\
\text { melalui aksi } \\
\text { penanaman pohon } \\
\text { produktif? }\end{array}$ & $22 / 8 / 5$ & $\begin{array}{l}\text { Setelah } \\
\text { mendengark an } \\
\text { materi dari para } \\
\text { narasumber, } \\
\text { apakah } \\
\text { Bapak/Ibu sudah } \\
\text { mengetahui } \\
\text { tentang } \\
\text { pentinngnya } \\
\text { program } \\
\text { penghijauan } \\
\text { melalui aksi } \\
\text { penanaman } \\
\text { pohon produktif? }\end{array}$ & $34 / 1 /-$ & $\begin{array}{l}\text { Sebanyak } 22 \text { peserta } \\
\text { sebenarnya sudah } \\
\text { memahami pentingnya } \\
\text { program penghijauan } \\
\text { melalui aksi penananam } \\
\text { pohon produktif, sementara } \\
13 \text { diantaranya mengaku } \\
\text { tidak tahu dan kurang tahu } \\
\text { mengenai pentingnya } \\
\text { program kegiatan ini. } \\
\text { Setelah mengikuti kegiatan, } \\
\text { 34 peserta menjadi tahu } \\
\text { pentingnya program } \\
\text { tersebut, dan hanya satu } \\
\text { orang yang masih mengaku } \\
\text { kurang tahu. }\end{array}$ \\
\hline
\end{tabular}




\begin{tabular}{|c|c|c|c|c|}
\hline $\begin{array}{l}\text { Apakah Bapak/Ibu } \\
\text { mengetahui } \\
\text { tentang program } \\
\text { penghijauan } \\
\text { pemerintah } \\
\text { melalui } \\
\text { pembangunan } \\
\text { Kebun Bibit Desa } \\
\text { (KBD)? }\end{array}$ & $7 / 11 / 17$ & $\begin{array}{l}\text { Setelah } \\
\text { mendapat } \\
\text { penjelasan dari } \\
\text { pemateri, apakah } \\
\text { Bapak/Ibu sudah } \\
\text { mengetahui } \\
\text { tentang program } \\
\text { penghijauan } \\
\text { pemerintah } \\
\text { melalui } \\
\text { pembentuka n } \\
\text { Kebun Bibit Desa } \\
\text { (KBD)? }\end{array}$ & $35 /-/-$ & $\begin{array}{l}\text { Terkait tema kegiatan, } \\
\text { sebanyak } 28 \text { peserta } \\
\text { mengaku kurang tahu dan } \\
\text { tidak mengetahui sama } \\
\text { sekali adanya kebijakan } \\
\text { pemerintah melalui } \\
\text { pembangunan Kebun Bibit } \\
\text { Desa (KBD), yang didanai } \\
\text { oleh APBN. Setelah } \\
\text { mengikuti kegiatan } \\
\text { pendampingan, masyarakat } \\
\text { yang diwakili peserta } \\
\text { keseluruhannya menjadi } \\
\text { tahu. }\end{array}$ \\
\hline $\begin{array}{l}\text { Apakah Bapak/Ibu } \\
\text { sebelumnya } \\
\text { mengetahui } \\
\text { tentang program- } \\
\text { program } \\
\text { pemerintah terkait } \\
\text { rehabilitasi } \\
\text { Daerah Aliran } \\
\text { Sungai (DAS)? }\end{array}$ & $10 / 14 / 11$ & $\begin{array}{l}\text { Setelah } \\
\text { mendengar } \\
\text { paparan } \\
\text { narasumber, } \\
\text { Apakah } \\
\text { Bapak/Ibu } \\
\text { mengetahui } \\
\text { tentang program- } \\
\text { program } \\
\text { pemerintah } \\
\text { terkait } \\
\text { rehabilitasi DAS? }\end{array}$ & $32 / 3 /-$ & $\begin{array}{l}\text { Sebanyak } 25 \text { peserta kurang } \\
\text { tahu dan tidak mengetahui } \\
\text { sama sekali mengenai } \\
\text { program- program } \\
\text { pemerintah terkait } \\
\text { rehabilitasi Daerah Aliran } \\
\text { Sungai (DAS). Setelah } \\
\text { mengikuti kegiatan, } \\
\text { sebanyak } 32 \text { peserta } \\
\text { menjadi tahu, dan hanya } \\
\text { tersisa } 3 \text { orang yang } \\
\text { mengaku masih kurang } \\
\text { tahu. }\end{array}$ \\
\hline $\begin{array}{l}\text { Apakah Bapak/Ibu } \\
\text { mengetahui } \\
\text { bahwa ada } \\
\text { program } \\
\text { pemerintah terkait } \\
\text { pemberian bibit } \\
\text { gratis bagi } \\
\text { masyarakat? }\end{array}$ & $10 / 11 / 14$ & $\begin{array}{l}\text { Setelah } \\
\text { mengikuti } \\
\text { kegiatan ini, } \\
\text { apakah } \\
\text { Bapak/Ibu } \\
\text { sebelumnya } \\
\text { mengetahui } \\
\text { bahwa ada } \\
\text { program } \\
\text { pemerintah } \\
\text { terkait } \\
\text { pemberian bibit } \\
\text { gratis bagi } \\
\text { masyarakat? }\end{array}$ & $34 / 1 /-$ & $\begin{array}{l}25 \text { peserta tidak mengetahui } \\
\text { adanya program pendukung } \\
\text { lainnya dalam bentuk } \\
\text { pemberian bibit pohon } \\
\text { produktif gratis pada } \\
\text { masyarakat. Setelah } \\
\text { mengikuti kegiatan, } \\
\text { sebanyak } 34 \text { peserta } \\
\text { menjadi tahu dan hanya satu } \\
\text { peserta yang masih kurang } \\
\text { tahu. }\end{array}$ \\
\hline
\end{tabular}

Sumber: Olahan Data. Keterangan: $\quad$ T : Tahu $\quad$ KT : Kurang Tahu $\quad$ TT : Tidak Tahu

Kegiatan dilanjutkan dengan penyerahan secara simbolis 3.000 bibit gratis pohon produktif kehutanan kepada masyarakat. Diantaranya bibit Gaharu, Nangka, Durian, Petai, dan berbagai bibit tanaman produktif lainnya. Setelah pelaksanaan kegiatan di dalam ruangan, acara ditutup dengan penanaman pohon oleh Bupati Siak, Kepala BPDASHL Indragiri Rokan, Camat Lubuk Dalam, perwakilan pengabdian masyarakat FIA Unilak, Kapolsek, dan lainnya di halaman kantor Camat Lubuk Dalam.

b. Membuat rencana PAR dari hasil laporan, melalui pemetaan wilayah dengan melihat potensi tiap Kampung, kebutuhan lingkungan masyarakat setempat, permintaan bibit sesuai lahan 
yang tersedia, dll. Ini dilakukan dalam beberapa kegiatan lapangan. Penerimaan proposal KBD dimulai pada periode Juli-10 Agustus 2020.

c. Proses pendampingan pembangunan KBD (pengorganisasian masyarakat dan pendampingan administratif). Dilakukan Verifikasi, sosialisasi kembali mengenai program KBD yang kali ini menyasar kepada kelompok masyarakat di setiap kampung, dilanjutkan dengan penyusunan rancangan KBD yang dilakukan dari tanggal 12-19 Agustus 2020. Setelah dilakukan verifikasi lapangan, dilakukan Nota Kesepahaman, Kontrak Swakelola, dan Pencairan dana tahap I (60\% atau Rp60 juta) oleh BPDASHL Indragiri Rokan KLHK pada tanggal 24-26 Agustus 2020.

Dari dana tahap I inilah pembangunan persemaian KBD mulai dikerjakan sampai dengan batas waktu 30 September 2020. Gambar 5 menunjukkan progres kegiatan pada setiap Kampung di Kecamatan Lubuk Dalam yang mendapat akses kebijakan pembangunan KBD.

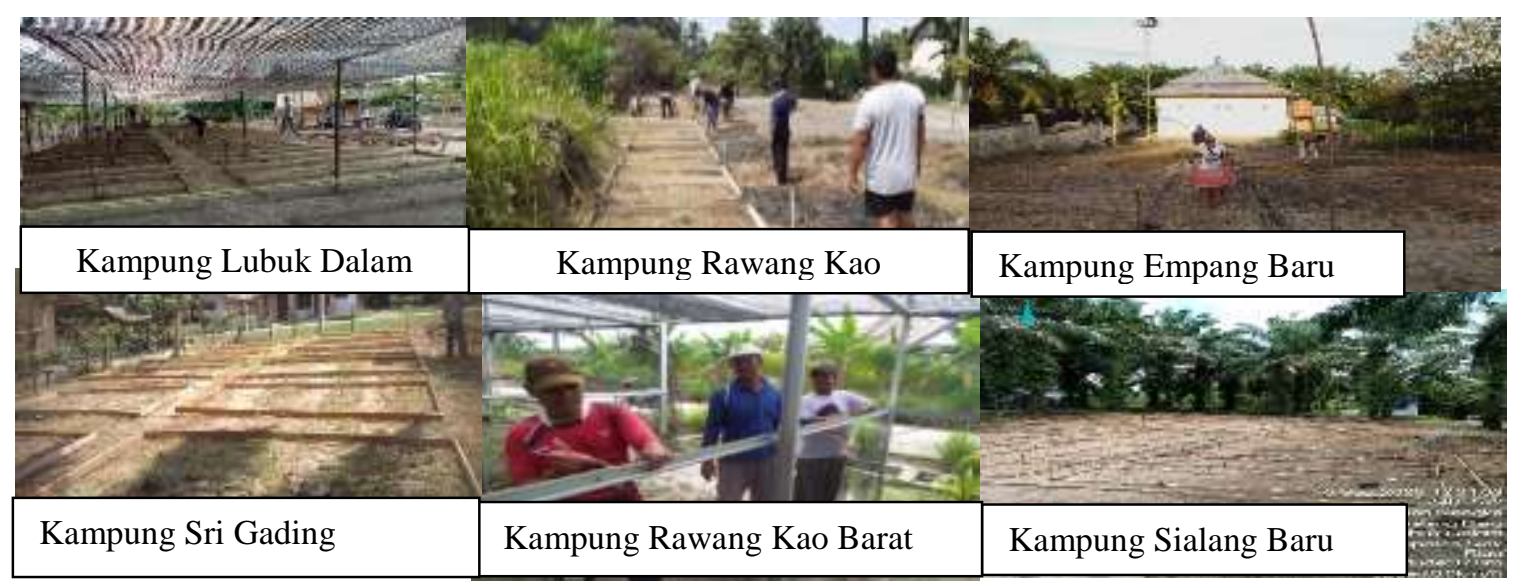

Gambar 5: Progres kegiatan pada setiap kampung di Kecamatan Lubuk Dalam yang mendapat akses kebijakan pembangunan KBD.

d. Melakukan evaluasi PAR pembangunan KBD di Kecamatan Lubuk Dalam secara keseluruhan melalui profil kelompok masyarakat penerima kebijakan dan survey online untuk mengetahui pandangan masyarakat terhadap kebijakan pembangunan KBD. Tabel 2 merupakan profil kelompok masyarakat penerima program KBD di Kecamatan Lubuk Dalam, Kabupaten Siak.

Tabel 2: Profil Kelompok Masyarakat Penerima KBD di Kec.Lubuk Dalam

\begin{tabular}{cllccc}
\hline $\begin{array}{c}\text { Nama } \\
\text { Kampung }\end{array}$ & $\begin{array}{c}\text { Nama } \\
\text { Kelompok }\end{array}$ & \multicolumn{1}{c}{ Jenis Tanaman } & $\begin{array}{c}\text { Target } \\
\text { Produksi } \\
\text { Bibit } \\
\text { (batang) }\end{array}$ & $\begin{array}{c}\text { Jumlah } \\
\text { Anggota } \\
\text { Kelompok }\end{array}$ & $\begin{array}{c}\text { Jumlah Dana } \\
\text { yang } \\
\text { Didapat } \\
\text { (Rp) }\end{array}$ \\
\hline $\begin{array}{c}\text { Lubuk } \\
\text { Dalam }\end{array}$ & $\begin{array}{l}\text { Kelompok } \\
\text { Kebun } \\
\text { Bibit Desa }\end{array}$ & $\begin{array}{l}\text { Matoa, Petai, Jengkol, } \\
\text { Pinang Batara, } \\
\text { Durian, Rambutan } \\
\text { Binjai, Mangga, } \\
\text { Lengkeng, Jambu } \\
\text { Black Kingkong }\end{array}$ & & & \\
& & & & \\
& & & & \\
\end{tabular}




\begin{tabular}{|c|c|c|c|c|c|}
\hline Sri Gading & $\begin{array}{l}\text { KBD Sri } \\
\text { Gading }\end{array}$ & $\begin{array}{l}\text { Pinang Batara, } \\
\text { Durian Okulasi, } \\
\text { Jengkol, Petai, } \\
\text { Manggis, Lengkeng, } \\
\text { Mangga Okulasi, } \\
\text { Jeruk Manis, Duku, } \\
\text { Matoa, Aplukat } \\
\text { okulasi }\end{array}$ & 40.000 & 15 & 100.000 .000 \\
\hline $\begin{array}{c}\text { Sialang } \\
\text { Palas }\end{array}$ & $\begin{array}{l}\text { KBD } \\
\text { Sialang } \\
\text { Palas }\end{array}$ & $\begin{array}{l}\text { Rambutan Binjai, } \\
\text { Jengkol, Petai, Duku, } \\
\text { Matoa, Sukun, Durian } \\
\text { Seedling, Durian } \\
\text { Okulasi, Lengkeng, } \\
\text { Nangka, Pinang } \\
\text { Batara, Aren }\end{array}$ & 40.000 & 15 & 100.000 .000 \\
\hline $\begin{array}{c}\text { Empang } \\
\text { Baru }\end{array}$ & $\begin{array}{l}\text { KBD Semi } \\
\text { Indah } \\
\text { Empang } \\
\text { Baru }\end{array}$ & $\begin{array}{l}\text { Lengkeng, Mangga, } \\
\text { Durian Okulasi, } \\
\text { Jambu Madu, Jengkol, } \\
\text { Durian Seeding, } \\
\text { Matoa, Alpukat, } \\
\text { Jeruk, Duku, Sukun }\end{array}$ & 40.000 & 15 & 100.000 .000 \\
\hline Rawang Kao & $\begin{array}{l}\text { KBD Tunas } \\
\text { Baru }\end{array}$ & $\begin{array}{l}\text { Lengkeng, Durian } \\
\text { Okulasi, Alpukat, } \\
\text { Jeruk, Duku, Manggis, } \\
\text { Jengkol, Durian } \\
\text { Seeding }\end{array}$ & 40.000 & 16 & 100.000 .000 \\
\hline $\begin{array}{c}\text { Rawang Kao } \\
\text { Barat }\end{array}$ & $\begin{array}{l}\text { KBD Tunas } \\
\text { Bangsa }\end{array}$ & $\begin{array}{l}\text { Durian Seeding, } \\
\text { Jengkol, Mangga, } \\
\text { Petai, Pinang Batara, } \\
\text { Jeruk, Sirsak, Jambu } \\
\text { Biji Merah, jabon }\end{array}$ & 40.000 & 20 & 100.000 .000 \\
\hline Sialang Baru & $\begin{array}{l}\text { KBD } \\
\text { Sialang } \\
\text { Baru }\end{array}$ & $\begin{array}{l}\text { Lengkeng, Mangga, } \\
\text { Jengkol, Nangka, } \\
\text { Alpukat, Kopi, Aren, } \\
\text { Pinang Batara, } \\
\text { Meranti, Merbau, } \\
\text { Mahoni }\end{array}$ & 40.000 & 20 & 100.000 .000 \\
\hline & & & 280.000 & 116 & 700.000 .000 \\
\hline
\end{tabular}

Sumber: Olahan Data Lapangan/BPDASHL Indragiri Rokan KLHK

Banyak pihak terlibat dalam program ini, diantaranya ada peran pemerintah pusat yang memiliki kebijakan KBD, peran pemerintah daerah selaku fasilitator, peran akademisi sebagai pendamping kelompok masyarakat, dan peran dari kelompok masyarakat selaku pelaksana pemulihan ekonomi sekaligus pemulihan lingkungan melalui program KBD.

Pembatasan waktu pelaksanaan kerja, menjadi kelemahan dari program KBD. Kelompok penerima program KBD mengalami kesulitan untuk pengadaan bibit dalam skala besar di tahap 
awal, sesuai dengan kontrak kerja yang diberikan. Diharapkan di masa yang akan datang, akses kebijakan KBD dapat disampaikan kepada kelompok penerima lebih cepat, sehingga pengadaan bibit juga dapat menjadi tambahan nilai ekonomi bagi anggota kelompok.

Sebanyak 19 orang perangkat organisasi KBD, yang berasal dari tujuh Kampung penerima program KBD, memberikan respon terhadap program KBD. Responden terdiri dari Pengendali KBD (Kepala Kampung/Dusun), Ketua Kelompok, Sekretaris, Bendahara, dan Pendamping. Tabel 3 merupakan hasil evaluasi PAR pembangunan KBD di Kecamatan Lubuk Dalam, Siak, berbasis indikator kinerja.

Tabel 3: Hasil Evaluasi PAR Pembangunan KBD Berbasis Indikator Kinerja

\begin{tabular}{|c|c|c|}
\hline No & Indikator Kinerja & Hasil/Pembahasan \\
\hline 1 & Masukan (input) & $\begin{array}{l}95,2 \% \text { menjawab sudah mendapatkan anggaran yang diberikan } \\
\text { untuk membangun KBD di Kampung masing-masing. Anggaran } \\
\text { tahap I yang sudah diterima sebesar Rp60 juta dari nilai komitmen } \\
\text { Rp100 juta per KBD. Sisanya mengaku tidak tahu. }\end{array}$ \\
\hline 2 & Keluaran (output) & $\begin{array}{l}95,2 \% \text { mengaku sudah diminta untuk membuat laporan dan } \\
\text { pertanggungjawaban administrasi terhadap anggaran pelaksanaan } \\
\text { KBD. Sisanya mengaku tidak diminta. }\end{array}$ \\
\hline 3 & Hasil (outcomes) & $\begin{array}{l}71,4 \% \text { menjawab bahwa setelah adanya program KBD, Kampung } \\
\text { mereka jadi memiliki unit persemaian yang mampu memproduksi } \\
\text { bibit pohon produktif untuk memenuhi kepentingan penghijauan } \\
\text { sekitar. } 19 \% \text { menjawab tidak tahu. } 9,5 \% \text { menjawab tidak } \\
\text { memiliki. }\end{array}$ \\
\hline 4 & Manfaat (benefit) & $\begin{array}{l}\text { Seluruh responden }\left(\begin{array}{lll}100 & \%\end{array}\right) \text { menjawab bahwa program } \\
\text { pembangunan kebun bibit desa memberikan manfaat secara } \\
\text { ekonomi dan sosial bagi masyarakat, terutama di masa pandemi. }\end{array}$ \\
\hline 5 & Dampak (impact) & $\begin{array}{l}\text { Seluruh responden }(100 \%) \text { meyakini bahwa KBD akan bermanfaat } \\
\text { untuk memperbaiki lingkungan kampung mereka di masa yang } \\
\text { akan datang. }\end{array}$ \\
\hline
\end{tabular}

Sumber: Olahan Data Survey Online

\section{KESIMPULAN}

Dari kegiatan pengabdian masyarakat ini diketahui bahwa masyarakat masih membutuhkan informasi, pendampingan administrasi kelompok, sampai pada pelaporan pertanggungjawaban program pemerintah yang berasal dari APBN. Peran akademisi menjadi penting sebagai jembatan memangkas kesenjangan informasi antara pemerintah dengan kelompok masyarakat yang berada di tingkat tapak, serta mendorong masyarakat melakukan transformasi dalam bentuk aksi bersama. Kerjasama antara pemerintah melalui kebijakan, akademisi yang melakukan pendampingan, dan masyarakat selaku pelaksana program kebijakan, terbukti menjadi kekuatan pendorong pemulihan ekonomi dan terwujudnya lingkungan yang lebih baik terutama di masa pandemi Covid-19.

\section{UCAPAN TERIMA KASIH}

Penghargaan dan terimakasih kepada unsur pimpinan Fakultas Ilmu Administrasi Universitas Lancang Kuning, segenap pimpinan dan jajaran BPDASHL Indragiri Rokan KLHK, Bupati Siak, Camat Lubuk Dalam beserta staff, para Kepala Kampung/Dusun se Kecamatan Lubuk Dalam, serta banyak pihak lainnya yang telah memberikan dukungan luar biasa hingga terlaksananya kegiatan pengabdian masyarakat ini dengan baik. 


\section{DAFTAR PUSTAKA}

Abdurrahim, Ali Yansyah.(2020). Membangun Resiliensi Penghidupan Rumah Tangga: Belajar dari Masyarakat Adat Samin. Diakses 2 September, dari https://kependudukan.lipi.go.id/id/kajian-kependudukan/ekologi-manusia/1021membangun-resiliensi-penghidupan-rumah-tangga-belajar-dari-masyarakat-adat-samin

Afandi, Agus,dkk. (2013). Modul Participatory Action Research (PAR) untuk Pengorganisasian Masyarakat (Community Organizing), Surabaya: LPPM UIN Sunan Ampel, hal 41-42 .

Afni Z. 2017. Indonesian Climate Change: Effort And Policies (Supporting Imt Gt Agreement On Environmetal Affairs). Proceedings of the 2 nd of International Seminar on Reinforcement of IMT-GT for Strengthening of Border Region, 24-25 April , 2017 Bangkok. Diakses 8 September 2020, dari https://intsob.com/wp-content/uploads/2016/12/Afni-Zulkifli.pdf

Afni Z. (2019). The Role of Transglobal Leadership for Forest andn Land Fire Control in Riau Province. International Journal of Innovation, Creativity and Change, 9 (5), 365

Bappenas.(2009). Pedoman Evaluasi dan Indikator Kinerja Pembangunan.

Chairani, Ikfina .(2020). Dampak Pandemi Covid-19 Dalam Perspektif Gender Di Indonesia. Jurnal Kependudukan Indonesia. Edisi Khusus Demografi dan Covid-19, 39-42.

Juliani, Henny.(2020). Analisis Yuridis Kebijakan Keuangan Negara dalam Penanganan Pandemi Covid-19 Melalui Peraturan Pemerintah Pengganti Undang-Undang Nomor 1 Tahun 2020. Administrative Law \& Governance Journal,3 (2), 329-348

Khairullah, Suprayogi, I, Sujatmoko,B.(2015). Kinerja Sub Das Siak Bagian Hulu Dalam Pengelolaan DAS Siak. JomFTeknik: Vol 2, 12

KLHK. 2020. KLHK Luncurkan 5 Agenda Dukung Pemulihan Ekonomi Nasional (PEN). Diakses 3 Februari 2021, dari http://pen.menlhk.go.id/detail/18

Maya, Daya.(2019). Mengenal Participatory Action Research. Diakses 3 Maret 2020, dari https://dayamaya.id/mengenal-participatory-action-research

Nizar, R., Siswati, L \& Zargustin, D. (2019). Bantuan Bibit Tanaman Untuk Membantu Meningkatkan Kualitas Lingkungan di Kelurahan Bambu Kuning Kecamatan Tenayan Raya, Kota Pekanbaru. Dinamisia: Jurnal Pengabdian Kepada Masyarakat, 3 , 144-148

Njurumana, Susila.(2006). Rehabilitasi Lahan Kritis Melalui Pengembangan Hutan Rakyat Berbasis Sistem Kaliwu Di Pulau Sumba. Jurnal Penelitian Hutan dan Konservasi Alam, 3 (1), 19-44

Peraturan Menteri LHK Nomor: P.2/MENLHK/SETJEN/KUM.1/1/202

Rawls, John. (2006). Teori Keadilan. Yogyakarta: Pustaka Pelajar

Surat Keputusan Dirjen PDASHL Nomor: SK.14/PDASHL/SET/DAS.2/4/2020

Tim. (2020). Menteri Siti Ungkap Pentingnya Rehabilitasi DAS di Tengah Pandemi COVID-19. Diakses 8 September, dari https://www.jpnn.com/news/menteri-siti-ungkap-pentingnyarehabilitasi-das-di-tengah-pandemi-covid-19

Tim.(2020). BPS: Dampak Covid-19, Penduduk Miskin Naik Jadi 26,42 Juta Orang". Diakses 1 September 2020, dari https://money.kompas.com/read/2020/07/15/150436926/bpsdampak-covid-19-penduduk-miskin-naik-jadi-2642-juta-orang?page=all.

Wahyunto, Dariah.(2014).Degradasi Lahan di Indonesia: Kondisi Existing, Karakteristik, dan Penyeragaman Definisi Mendukung Gerakan Menuju Satu Peta. Jurnal Sumberdaya Lahan, Vol 2; 81-93

Widianto, Ahmad Arif.(2013). Menjembatani Aksesibilitas Masyarakat Miskin Pada Pelayanan Kesehatan Melalui Institusi Lokal. Sosiologi Reflektif, 8 (1), 50.

Wiratno.(2020). Catatan Pengembaraan Intelektual 2009-2019. KSDAE 